\title{
ARTI PENTING HUKUM ANTARTATA HUKUM UNTUK INDONESIA
}

\author{
(The Importance of Interlegal Law for Indonesia)
}

\author{
Yu Un Oppusunggu \\ Fakultas Hukum Universitas Indonesia \\ Jl. Prof. Mr. Djokosoetono, Kampus UI, Depok, 16424 \\ Email: yu_oppu@ui.ac.id
}

Naskah diterima: 15 Juni 2018; revisi: 10 Agustus 2018; disetujui: 10 Agustus 2018

\begin{abstract}
Abstrak
Hukum Antartata Hukum (HATAH) memiliki arti penting, karena hukum di Indonesia bersifat plural. Permasalahan hukum banyak disebabkan oleh ketidakcermatan pembuat dan pelaksana hukum dalam memahami pluralisme hukum Indonesia. Pengabaian terhadap pluralisme hukum akan mengakibatkan ketidakpastian hukum dan/atau ketidakadilan, sehingga akan menghambat pembangunan ekonomi nasional. Oleh karena itu, dalam artikel ini Penulis akan membahas arti penting HATAH saat ini dengan pendekatan historis. Selain itu dibahas pula bahwa perjanjian-perjanjian internasional yang menjadi bagian dari HATAH Indonesia, sangat mempengaruhi pengembangan ekonomi nasional Indonesia dan berpotensi adanya benturan kepentingan antara kepentingan nasional dan tuntutan internasional. Dengan menggunakan pendekatan historis dalam membahas permasalahan di atas, dapat disimpulkan bahwa kunci menyelesaikan permasalahan hukum nasional ada pada pemahaman yang benar tentang pluralisme hukum dan ilmu hukum antartata hukum.

Kata Kunci: hukum perdata internasional, hukum antartata hukum, pluralisme hukum, pembangunan hukum
\end{abstract}

\begin{abstract}
Proficiency in interlegal law is inevitable given the fact that law in Indonesia is pluralistic. Many legal problems caused by the negligence of lawmaker and law enforcement toward legal pluralism in Indonesia. This negligence will cause legal uncertainty and/or injustice that may retard the national economy development. This article discusses the importance of interlegal law for Indonesia using historical approach. The author also elaborates some international conventions which have become part of interlegal law in Indonesia that impact the national economy development and may cause conflict between national interest and international demand. Using historical exposition through literature and legislation research, the author points out that the key to solve national legal problem lies on understanding of legal pluralism and the science of interlegal law.
\end{abstract}

Keywords: private international law, interlegal law, legal pluralism, legal development 


\section{A. Pendahuluan}

Artikel ini menjelaskan tentang pentingnya hukum antartata hukum (HATAH) bagi Indonesia. Penulis berargumen bahwa permasalahanpermasalahan hukum banyak disebabkan oleh ketidakcermatan pembuat dan pelaksana hukum dalam memahami pluralisme hukum Indonesia. Oleh karena pluralisme merupakan suatu conditio sine qua non dalam hukum Indonesia, maka segala usaha harus tersusun atas dasar pemahaman yang benar akan kemajemukan hukum yang ada. Demikian juga halnya dengan pembangunan ekonomi nasional di era globalisasi.

Bagian kedua artikel ini menjelaskan metode atau pendekatan yang penulis gunakan dalam artikel ini. Bagian pembahasan memaparkan tentang cabang ilmu HATAH, yang khas Indonesia. Pemaparan dimulai dengan menjelaskan latar belakang mengapa HATAH diajarkan dalam pendidikan tinggi hukum Indonesia. Meskipun pembentuk undangundang telah berusaha untuk membuat peraturan perundang-undangan yang bersifat nasional, namun sebagaimana penulis tunjukkan pluralisme tersebut masih akan terus ada. Pengabaian terhadap pluralisme hukum akan mengakibatkan ketidakpastian hukum dan/atau ketidakadilan. Pada gilirannya, hal tersebut akan menghambat pembangunan ekonomi nasional. Pembahasan berlanjut dengan perjanjian-perjanjian internasional yang menjadi bagian dari HATAH Indonesia.
Penulis akan menunjukkan bahwa perjanjianperjanjian internasional tersebut telah dan akan terus mempengaruhi pengembangan ekonomi nasional Indonesia. Di samping itu, terdapat benturan antara kepentingan nasional dengan komitmen internasional atau usaha Indonesia untuk menarik modal asing. Bagian terakhir memberikan kesimpulan singkat, serta saran tentang pembangunan ekonomi nasional yang tepat strategi berdasarkan hukum yang berlaku di Indonesia.

\section{B. Metode Penelitian}

Penulis akan menggunakan pendekatan historis dalam membahas tentang HATAH. Pendekatan ini dipilih untuk memaparkan dengan gamblang hakikat hukum Indonesia yang tidak banyak berubah. Penulis menelusuri literatur dan peraturan perundang-undangan untuk memeriksa aspek-aspek antartata hukum.

\section{Pembahasan}

\section{Arti Penting HATAH Dalam Sistem Hukum Indonesia}

Pohon ilmiah (science tree) hukum maupun pembidangan tata hukum Indonesia tidak secara konsisten mencantumkan HATAH sebagai salah satu cabang ilmu hukum. ${ }^{1}$ Namun dalam sejarahnya HATAH adalah salah satu mata kuliah tertua yang sudah diajarkan sejak pendidikan tinggi hukum diselenggarakan di Nusantara. ${ }^{2}$ Di masa Hindia Belanda, HATAH mempunyai dua nama Intergentiel Recht (Hukum Antargolongan) dan

1 Soerjono Soekanto, "Pokok-pokok Penyusunan Silabus Kurikulum Fakultas Hukum," Hukum dan Pembangunan 5 (1986): 444-445, tidak mencantumkan HATAH. Sementara penyusunan kurikulum yang berdasarkan pohon ilmiah hukum memasukkan HATAH ke dalam hukum perdata. Lih. Padmo Wahyono, Pendidikan Tinggi Hukum di Indonesia (Jakarta: Firma Widjaya dan Yayasan Tritura '66, 1990), hlm. 212-213.

2 Mata kuliah HATAH tidak ada di kurikulum Rechtschool (Sekolah Hukum), setara sekolah menengah atas, yang berdiri secara resmi pada tahun 1909 sebagai Opleidingschool voor Inlandsche Rechtskudingen (Sekolah Pendidikan bagi Ahli Hukum Pribumi). Lih. pasal 4:1 Reglement voor de Opleidingsschool voor Inlandsche rechtskundingen [Peraturan tentang Sekolah Pendidikan untuk Ahli Hukum Pribumi], S. 1909-93. 
Internationaal Privaatrecht (Hukum Perdata Internasional). ${ }^{3}$ Ketika Rechtshoogeschool (Sekolah Tinggi Hukum) beroperasi pada tahun 1924, keduanya menjadi mata kuliah wajib. ${ }^{4}$

Yang bertanggung jawab akan adanya mata kuliah Intergentiel Recht adalah $\mathrm{R}$. D. Kollewijn. Dalam persiapan pembukaan Rechtshoogeschool, Kollewijn mengusulkan kepada Paul Scholten, yang mendapatkan tugas khusus dari Menteri Wilayah Jajahan, agar Sekolah Tinggi Hukum di Hindia Belanda (baca: Indonesia) mempunyai mata kuliah intergentiel recht. ${ }^{5}$ Meski Cornelis van Vollenhoven sudah menggunakan istilah tersebut dalam disertasi dan pidato pengukuhan guru besarnya, ${ }^{6}$ sebagai mata kuliah nama intergentiel recht masihlah asing bagi Scholten. Sebabnya, dalam mimbar mata kuliah di universitas-universitas Eropa tidak ada mata kuliah Intergentiel Recht. $^{7}$ Namun Kollewijn berhasil menyakinkan mantan gurunya tersebut. ${ }^{8}$ Beliau pun dipercaya untuk menjadi guru besar untuk Intergentiel Recht, Internationaal Privaatrecht, dan Inleiding tot de Rechtswetenschap (Pengantar IImu Hukum). ${ }^{9}$ Setelah Kollewijn terpaksa pulang ke Belanda karena alasan kesehatan, J. H. A. Logemann menggantikannya sebagai guru besar secara ad interim untuk Intergentiel Recht dan Internationaal Privaatrecht (1932-1936). Selanjutnya kursi tersebut secara berturut-turut diduduki oleh W. F. Wertheim (1936-1942), W. L. G. Lemaire (1946-1950), dan G. J. Resink (1950-1958). ${ }^{10}$ Sudargo Gautama (terlahir Gouw Giok Siong) menggantikan Resink pada tahun 1958, dan terus memegang jabatan guru besar sampai lima dekade kemudian. ${ }^{11}$

Lih. Pasal 9:1 Hooger Onderwijs-ordonnatie [Ordonansi Pendidikan Tinggi], S. 1924-456.

4 Lih. misalnya, Rechtshoogeschool, Jaarboekje der Rechtshoogeschool te Batavia 1927 [Buku Tahunan Sekolah Tinggi Hukum di Batavia 1927] (Batavia: G. Kolff \& Co., 1927), hlm. 10-11. Setelah Indonesia merdeka, sekolah ini kemudian bertransformasi menjadi Fakultas Hukum Universitas Indonesia.

5 Paul Scholten, yang termasyhur sebagai Scholten van Amsterdam, adalah guru besar hukum perdata di Universitas Amsterdam. Beliau mendapatkan tugas dari Ratu Belanda untuk mempersiapkan sekolah tinggi hukum di Hindia Belanda. Lih. St. Malikul Syah., "Mr. R. D. Kollewijn: Intergentiel recht Verzamelde opstellen over intergentiel privaatrecht", Hukum 3-4 (1956): 7-8.

6 Wirjono Prodjodikoro, Hukum Antar-Golongan di Indonesia (Bandung: Vorkink-van Hoeve, 1962), hlm. 7.

7 L. J. van Apeldoorn, Inleiding tot de Studie van het Nederlandsche Recht, misalnya, sama sekali tidak membahas tentang intergentiel recht. Sejak tahun 1954, buku ini sudah diterjemahkan oleh Oetarid Sadino sebagai Pengantar Ilmu Hukum. Penanggalan kata "Belanda" dari judul dapat memberikan kesan bahwa buku ini adalah pengantar ilmu hukum di Indonesia. Berbeda dengan van Apeldoorn, W. L. G. Lemaire, Het Recht in Indonesia [Hukum di Indonesia] (Bandung: Uitgeverij W. van Hoeve, 1955), membahas secara khusus intergentiel dalam satu bab.

8 Di kemudian hari ia memberikan penjelasan tertulis dalam R. D. Kollewijn, "Conflicts of Western and NonWestern Law," The International Law Quarterly 4 (1951): 313-314. Indonesia adalah negara pertama yang memberikan perhatian bagi ilmu ini. Lih. Gouw Giok Siong, "Tinjauan Buku: Prof. Mr. R. D. Kollewijn, Intergentiel Recht Verzamelde opstellen over intergentiel privaatrecht," Majalah Hukum dan Masjarakat, 4 (1956): 40. Atas kontribusinya, Kollewijn mendapatkan julukan sebagai "bapak hukum antargolongan". Lih. Sudargo Gautama, Hukum Antargolongan: Suatu Pengantar (Jakarta: Ichtiar Baru van Hoeve, 1993), hlm. 21.

9 G.J.W. Steenhoff, “Roeland Duco Kollewjin (1892-1972)”, dalam Gerard J. Tanja (ed.), The Moulding of International Law: Ten Dutch Proponents (The Hague: T. M. C. Asser Institute, 1995), hlm. 381.

10 Lih. misalnya Moh. Koesnoe, "Arti, Tempat, dan Sifat Hukum Intergentil", Majalah Hukum dan Masyarakat 2 (1957): 17. Lih. juga S. Pompe dan C. de Waaij-Vosters, “The End of Hukum Antargolongan," Bijdragen tot de Taal, Lad- en Volkenkunde 145 (1989): 365.

11 Lih. Yu Un Oppusunggu, "In Memoriam Prof. Mr. Dr. Sudargo Gautama," Jurnal Hukum dan Pembangunan, 38 (2008): 439-448. Lih. juga, Yu Un Oppusunggu, "Gautama, Sudargo", Southeast Asian Personalities of Chinese Descent: A Biographical Dictionary (Singapore: The Chinese Heritage Center, Nanyang Technology University, 2012), hlm. 273-276. Sekarang jabatan tersebut secara emeritus dipegang oleh mantan asistennya, Prof. Dr. Zulfa Djoko Basuki, yang juga menjadi guru besar di Sekolah Tinggi Hukum Militer. 
HATAH adalah nama ilmiah yang diciptakan Sudargo Gautama untuk menggantikan, sekaligus mencakup, hukum perselisihan (collisierecht), hukum pertikaian (conflictenrecht, conflict of laws), dan hukum perdata internasional (private international law). ${ }^{12}$ Harapan beliau, nama ilmiah tersebut dapat memberikan gambaran tentang lingkup permasalahan hukum yang menjadi bahasan. Secara ilmiah, lingkup pembahasan HATAH di Indonesia terbagi menjadi dua. ${ }^{13}$ HATAH Intern, yang menganalisis permasalahan di lingkup nasional akibat adanya pluralisme hukum, mencakup hukum antargolongan (intergentiel recht, interpersonal law, interracial law), hukum antarwaktu (intertemporal law), dan hukum antartempat (interlocal law). ${ }^{14}$ Gautama mendefinisikan HATAH Intern sebagai:

"Keseluruhan peraturan dan keputusanhukum yang menunjukkan stelsel-hukum manakah yang berlaku atau apakah yang merupakan hukum, jika hubungan-hubungan dan peristiwa-peristiwa antara warga (warga) negara dalam satu negara, memperlihatkan titik-titik pertalian dengan stelsel-stelsel dan kaidah-kaidah hukum yang berbeda dalam lingkungan-kuasa-waktu, tempat pribadi dan soal-soal." ${ }^{15}$

Sementara HATAH Ekstern adalah nama ilmiah Indonesia untuk menggantikan istilah hukum perdata internasional. Berbeda dengan HATAH Intern yang berkutat dengan masalah-masalah hukum secara nasional, HATAH Ekstern menganalisis permasalahan hukum yang mempunyai unsur asing. Gautama mendefinisikannya sebagai:

"Keseluruhan peraturan dan keputusanhukum yang menunjukkan stelsel-hukum manakah yang berlaku atau apakah yang merupakan hukum, jika hubungan-hubungan dan peristiwa-peristiwa antara warga (warga) negara pada satu waktu tertentu memperlihatkan titik-titik pertalian dengan stelsel-stelsel dan kaidah-kaidah hukum dari dua atau lebih negara, yang berbeda dalam lingkungan-lingkungan-kuasa-tempat, (pribadi) dan soal-soal." 16

Meskipun Kollewijn sudah memaparkan secara ilmiah intergentiel recht (baca: HATAH Intern) sebagai suatu cabang ilmu hukum, ${ }^{17}$ pengakuan dari dunia praktik baru terjadi kemudian. Hakim Landraad $^{18}$ Malang dengan cermat melihat permasalahan hukum antargolongan perkara utang-piutang antara kreditur dan debitur yang tunduk pada hukum yang berbeda. ${ }^{19}$ Tepatlah kiranya sorakan yang dikumandangkan oleh Wertheim ketika memberikan anotasi atas komentar tersebut, "Van Malang begint de victorie!" Dari Malang

12 Sudargo Gautama, Pengantar Hukum Perdata Internasional Indonesia (Jakarta: Bina Cipta, 1987) hlm. 7-8. (Selanjutnya, Gautama, Pengantar.)

13 Lih. Yu Un Oppusunggu dan Gary F. Bell, "Indonesia”, dalam Jürgen Basedow, Gissela Ruhl, Franco Ferrari, dan Pedro de Miguel Asensio (eds.), Encyclopedia of Private International Law, Vol. 3 (London: Edward Elgar Publishing, 2017), hlm. 2165-2169.

14 Lih. Sudargo Gautama, Hukum Antargolongan: Suatu Pengantar (Jakarta: Ichtiar Baru van Hoeve, 1993), hlm. 4146. Di samping itu, hukum antarwenang pada hakikatnya merupakan bagian dari HATAH Intern.

15 Gautama, Pengantar, hlm. 21. Cetak tebal oleh penulis.

16 Ibid. Cetak tebal oleh penulis.

17 Lih. misalnya R. D. Kollewijn, "Intergentiel Privaatrecht," Indisch Tijdschrift van het Recht 131 (1930): 517-533.

18 Landraad adalah pengadilan tingkat pertama di Hindia Belanda yang mempunyai kompetensi untuk mengadili perkara-perkara yang pihak-pihaknya masuk ke dalam golongan Indonesia (inlanders). Lih. pasal 94 Reglement op de Rechterlijke Organisatie en het Beleid der Justitie in Indonesië [Peraturan Susunan Kehakiman dan Kebijaksanaan Mengadili di Indonesia], S. 1847-23 jo. 1848-57.

19 Ldr. Malang, 16 Februari 1938, T. 148 (1939) 764, sebagaimana terdapat dalam Gouw Giok Siong, Himpunan Keputusan-keputusan Hukum Antargolongan (Jakarta: Penerbitan Universitas, 1959), hlm. 9-12. 
mulailah kemenangan! ${ }^{20}$ Semenjak itu, pengadilan-pengadilan di Hindia Belanda, dan kemudian Indonesia, mengakui pluralisme hukum yang ada dalam mengadili perkara. ${ }^{21}$

HATAH, baik intern maupun ekstern, kemudian mendapatkan pembahasan khusus dalam ilmu hukum di Indonesia. ${ }^{22}$ Mengingat pluralisme yang ada, ahli hukum asing menghadapi kesulitan untuk memasukkan hukum Indonesia ke dalam keluarga hukum (legal family) yang ada, dan terpaksa melakukan simplifikasi. ${ }^{23}$

Pluralisme hukum di Indonesia berakar pada pluralisme penduduk sejak masa lalu, yang kemudian dilembagakan secara formal oleh pengaturan hukum di masa penjajahan yang demiki- an kompleks. ${ }^{24}$ Sejak abad XVIII William Marsden telah menunjukkan keragaman hukum di Sumatera. ${ }^{25}$ Kemudian, van Vollenhoven, dengan menggunakan bahasa sebagai dasar pengelompokkan, membagi Nusantara ke dalam 19 lingkungan hukum adat (adat rechtskringen). ${ }^{26}$ la menentang upaya unifikasi hukum yang diusung oleh para sarjana yang dikenal sebagai Mazhab Utrecht, dan mengadvokasi pluralisme hukum. ${ }^{27}$ Kollewijn kemudian mengadvokasi kesetaraan antarsistem hukum - Barat dan adat - sebagai dasar dari pluralisme hukum Indonesia. ${ }^{28}$

Secara sederhana penduduk Nusantara terbagi menjadi warganegara Belanda, kaulanegara Belanda, dan orang asing. ${ }^{29}$ Selain itu penduduk digolongkan menurut pembedaan
Indonesia Sebelum Perang Dunia II (Jakarta: Prandya Paramita, 1981). Demikian juga halnya dengan Soediman Kartohadiprodjo, Pengantar Tata Hukum di Indonesia (Jakarta: Ghalia Indonesia, 1993). Soebijono Tjitrowinoto membahas HATAH ekstern dan intern dalam dua bab terpisah. Soebijono Tjitrowinoto, Ichtisar tentang Hukum di Indonesia (Malang: Rahma Kongsi, 1953). Demikian juga E. Utrecht, Pengantar dalam Hukum Indonesia (Jakarta: Penerbitan dan Balai Buku Indonesia, 1961). Ada juga yang menuliskan buku untuk membahas HATAH secara lebih luas, Wirjono Prodjodikoro, Hukum Antar-Golongan di Indonesia (Bandung: Sumur, 1962).

23 Yu Un Oppusunggu, Sudargo Gautama and the Development of Indonesian Public Order: A Study on the Application of Public Order Doctrine in a Pluralistic Legal System, disertasi (Seattle: University of Washington, 2015), hlm. 2122. (Selanjutnya, Oppusunggu, Disertasi.)

24 Lih. misalnya Supomo, hlm. 24-25.

25 William Marsden, The History of Sumatra, ed. ke-3 (Oxford: Oxford University Press, 1966), hlm. 242 dan 302.

26 J. F. Holleman (ed.), Van Vollenhoven on Indonesian Adat Law (Selection from Het Adatrecht van NederlandschIndië (Volume I, 1918; Volume II, 1931) (The Hague: Martinus Nijhoff, 1981), hlm. 41-53.

27 Sudargo Gautama, Pembaharuan Hukum di Indonesia (Bandung: Alumni, 1973), hlm. 17-20. (Selanjutnya, Gautama, Pembaharuan.) Lih. juga Soetandyo Wignjosoebroto, Dari Hukum Kolonial ke Hukum Nasional: Suatu Kajian tentang Dinamika Sosial-politik dalam Perkembangan Hukum Selama Satu Setengah Abad di Indonesia, 1840-1990 (Jakarta: RajaGrafindo, 1994), hlm. 178, dan Peter Burns, Concept of Law in Indonesia (Leiden: KITLV Press, 2004), hlm. 77-89.

28 Karena posisinya ini Kollewijn kemudian terlibat dalam perdebatan public dengan Henry Solus, guru besar di Universitas Poitiers, Perancis yang berpendirian bahwa hukum wilayah jajahan harus mengikuti negara penjajah. Dengan pendirian ini, Solus membenarkan hukum di Indo-Cina harus mengadopsi hukum Perancis. Lih. misalnya, Sudargo Gautama, "Prof. Djokosoetono dan Hukum Antar Tata Hukum", dalam Selo Soemardjan (ed.), Guru Pinandita, Sumbangsih untuk Prof. Djokosoetono, SH (Jakarta: Lembaga Penerbitan Fakultas Ekonomi Universitas Indonesia, 2006), hlm. 248. (Selanjutnya, Soemardjan, Pinandita.)

29 Kaulanegara adalah warga jajahan, yang secara hukum berada di bawah warganegara. Lih. Supomo, hlm. 1335; Gouw Giok Siong, Warganegara dan Orang Asing (Jakarta: Keng Po, 1958), hlm. 17-22. Lih. juga, Ko Swan Sik dan Teuku Moh. Rhadie, "Nationality and International Law in Indonesian Perspective", dalam Ko Swan Sik (ed.), Nationality and International Law in Asian Perspective (Dordrecht: Martinus Nijhoff, 1990), hlm. 131-134. Tentang penduduk Hindia Belanda, lih. misalnya J. Stroomberg, Hindia Belanda 1930, diterjemahkan oleh Heri Apriyono, (Yogyakarta: IRCiSoD, 2018), hlm. 55-61. 
pokok: Belanda dan pribumi. Mereka yang bukan Belanda atau pribumi (inlanders) akan dipersamakan sebagai salah satu dari kedua golongan tersebut. ${ }^{30}$

Sumber utama dari pluralisme hukum di Indonesia adalah dua pasal dari Wet op de Staatsinrichting van Nederlandsch-Indië (Peraturan Ketatanegaraan Indonesia di Zaman Pemerintahan Belanda, IS). ${ }^{31}$ Pasal 131:1 IS mengatur tentang hukum perdata dan dagang berlaku bagi seluruh golongan rakyat (bevolkingsgroep), beberapa golongan rakyat, atau sebagian dari golongan rakyat. ${ }^{32}$ Kecuali ada kebutuhan hukum khusus, bagi golongan Eropa (Europeanen) berlaku hukum yang ada di Belanda. Hal ini dikenal sebagai asas konkordansi (concordantiebeginsel). ${ }^{33}$ Untuk golongan Indonesia dan golongan Timur Asing (Vreemde Oosterlingen) dapat berlaku hukum yang sama dengan golongan Eropa. ${ }^{34}$ Namun hukum yang utama bagi mereka adalah hukum adat. Pengaturan yang demikian didasarkan pada asas penghormatan hukum adat. ${ }^{35}$ Kedua golongan ini dapat juga menundukkan diri kepada hukum yang berlaku bagi golongan Eropa. ${ }^{36}$

Siapa sajakah yang masuk ke dalam golongangolongan rakyat yang ada? Berdasarkan dikotomi awal di atas, orang-orang Arab, Moor, Tionghoa, dan pemeluk agama Islam lainnya dipersamakan dengan pribumi. $^{37}$ Kemudian Pemerintah Kolonial melakukan pemekaran. Golongan Timur Asing diadakan untuk memisahkan penduduk Tionghoa dari golongan pribumi. ${ }^{38}$ Lebih lanjut, semua penduduk yang "asing" dipindahkan ke golongan Timur Asing. Sebagai akibatnya, ada dua golongan Timur Asing yang tunduk pada hukum Eropa: Tionghoa (Chinezen Vreemde Osterlingen) dan non-Tionghoa (Vreemde Oosterlingen nietChinezen). ${ }^{39}$ Namun perlu dicatat, berlakunya hukum Eropa telah terjadi secara bertahap

30 Pasal 109 Reglement op het beleide der Regering van Nederlandsch-Indië, S. 1855-2. Lebih lanjut, Supomo, hlm. 24-25.

31 Wet op de Staatsinrichting van Nederlandsch-Indië [Undang-Undang tentang Ketatanegaraan Hindia Belanda]. Peraturan Ketatanegaraan yang merupakan kuasi konstitusi ini tetap berlaku berdasarkan Pasal I Aturan Peralihan Undang-Undang Dasar Negara Republik Indonesia Tahun 1945.

32 Pluralisme untuk hukum pidana berakhir setelah pada tahun 1 Januari 1918 semua penduduk tunduk pada Kitab Undang-Undang Hukum Pidana (Wetboek van Strafrecht voor Nederlandsch-Indië), S. 1915-732 jis 1917-497, 645. Pasal 2 KUHP secara tegas menyatakan bahwa, "Ketentuan pidana dalam perundang-undangan Indonesia berlaku bagi setiap orang yang melakukan suatu tindak pidana di Indonesia." Cetak tebal oleh penulis.

33 Pasal 131:2(a) IS.

34 Pasal 131:2(b) IS.

35 Lih. misalnya Thung Tiang Piet, "Cita-cita Kodifikasi dan Unifikasi di Indonesia dan Perbandingan Hukum," Majalah Hukum dan Masyarakat 3 (1958): 4.

36 Pasal 131:4 IS.

37 Lih. catatan kaki no. 31.

38 Pembedaan ini mulai ditetapkan pada 31 Desember 1906, namun baru efektif berlaku 1 Januari 1920. C. Fasseur, "Colonial Dilemma: Van Vollenhoven and the Struggle Between Adat Law and Western Law in Indonesia", dalam W. J. Mommsen dan J. A. de Moor, European Expansion and Law - The Encounter and Indigenous Law in 19th-and 20th-Century Africa and Asia (Oxford/New York: Berg, 1992), hlm. 238.

39 Berturut-turut berdasarkan Bepalingen voor geheel Indonesië betreffende het burgerlijk en handelsrecht van de Chineezen [Penetapan untuk seluruh Indonesia tentang hukum perdata dan hukum dagang untuk Tionghoa], S. 1917-129, dan Bepalingen voor geheel Indonesië betreffende het het burgerlijk en handelsrecht der Vreemde Ooosterlingen Andere dan Chineezen [Penetapan untuk seluruh Indonesia tentang hukum perdata dan hukum dagang untuk Timur Asing Selain Tionghoa], S. 1924-556. 
sebelum "golongan Timur Asing" menjadi suatu golongan rakyat terpisah. ${ }^{40}$

Pasal 163 IS mengatur tentang golongan rakyat. Yang termasuk ke dalam golongan Eropa adalah (1) semua orang Belanda, (2) semua orang Eropa, (3) semua orang Jepang dan mereka yang berasal dari negara yang hukum keluarga sama dengan Belanda, dan (4) anakanak yang sah atau yang diakui sah berdasarkan peraturan perundang-undangan dari orangorang yang termasuk dalam (1)-(3). ${ }^{41}$ Golongan Indonesia adalah orang Indonesia asli, yang belum masuk ke dalam golongan lain atau tunduk pada ordonansi tertentu. ${ }^{42}$ Sementara golongan Timur Asing adalah mereka yang tidak termasuk ke dalam golongan Eropa dan Indonesia. ${ }^{43}$

Pluralisme hukum ini tidak hanya terbatas pada hukum perdata, namun juga hukum dagang serta bentuk badan hukum. Untuk golongan Eropa dan Timur Aing, karena tunduk pada Kitab Undang-Undang Hukum Perdata dan Kitab Undang-Undang Hukum Dagang, bentuk badan hukum yang tersedia adalah naamloze venootschap (NV, persekutuan tanpa nama, yang kemudian diterjemahkan menjadi perseroan terbatas). ${ }^{44}$ Sedangkan Indonesische Maatschappij op Aandeelen (IMA, maskapai andil Indonesia) adalah badan hukum yang hanya dapat didirikan oleh orang-orang yang termasuk dalam golongan Indonesia. ${ }^{45}$

Kemerdekaan Indonesia tidak mengakhiri pluralisme hukum ini. Aturan Peralihan dalam Undang-Undang Dasar, yang berfungsi untuk menghindari kekosongan hukum, memastikan kesinambungan status quo. ${ }^{46}$ Meskipun pascaProklamasi penduduk Indonesia digolongkan sebagai warga negara dan orang asing, ${ }^{47}$ hukum yang berlaku bagi pribadi kodrati tetap bersifat plural. ${ }^{48}$ Dalam Lie Kwie Hien v. Tjin Tjheuw

$40 \quad$ Bepalingen, houdende toepasselijk verklaring van de Europesche Wetgeving op de met de Inlandsche Gelijkgestelde Bevolking [Penetapan, Memuat Pernyataan Keberlakuan Peraturan Eropa terhadap Golongan Rakyat Indonesia], S. 1855-79-129 dan Toepasselijk-verklaring op de Inlandsche en met deze Gelijkgestelde Bevolking van de Artikelen 1601, 1602 en 1603 van het Burgerlijk Wetboek [Pernyataan Keberlakuan Pasal-pasal 1601, 1602 dan 1603 dari Kitab Undang-Undang Hukum Perdata terhadap Golongan Rakyat Indonesia dan Yang Dipersamakan], S. 1879-256. Yang menjadi alasan pemberlakuan hukum Eropa adalah kepentingan dagang penjajah. Lih. R. D. Kollewijn, Intergentiel Recht (Bandung: van Hoeve, 1955), hlm. 156. Lih. juga, Sunaryati Hartono, Dari Hukum Antar Golongan ke Hukum Antar Adat (Bandung: Citra Aditya Bakti, 1991), hlm. 35.

41 Pasal 163:2 IS.

42 Pasal 163:3 IS.

43 Pasal 163:4 IS.

44 Pasal 35-56 Wetboek van Koophandel [Kitab Undang-Undang Hukum Dagang], S. 1847-23.

45 Pasal 2 Ordonnantie op de Inlandsche Maatschappijen op Aandeelen [Peraturan tentang Maskapai Andil Indonesia], S. 1939-569.

46 Lih. Pasal II Aturan Peralihan Undang-Undang Dasar 1945 mengatur bahwa, "Segala badan negara dan peraturan yang ada masih langsung berlaku selama belum diadakan yang baru menurut Undang-Undang Dasar ini." Pasal 142 Undang-Undang Dasar Sementara Republik Indonesia mengatur serupa ketika menyatakan bahwa, "Peraturanperaturan, undang-undang dan ketentuan-ketentuan tata-usaha yang sudah ada pada tanggal 17 Agustus 1950 tetap berlaku dengan tidak berubah sebagai peraturan-peraturan dan ketentuan-ketentuan Republik Indonesia sendiri, selama dan sekedar peraturan-peraturan dan ketentuan-ketentuan itu tidak dicabut, ditambah atau diubah oleh undang-undang dan ketentuan-ketentuan tata-usaha atas kuasa Undang-Undang Dasar ini."

47 Lih. pasal 26 UUD 1945 (Naskah Asli), dan Undang-Undang No. 3 Tahun 1946 tentang Warga Negara dan Penduduk Negara

48 Setelah Reformasi kesinambungan keberlakuan hukum tersebut diatur oleh Pasal I Aturan Peralihan UndangUndang Dasar Negara Republik Indonesia Tahun 1945 (Perubahan Keempat) yang menyatakan bahwa, "Segala peraturan perundang-undangan yang ada masih tetap berlaku selama belum diadakan yang baru menurut Undang-Undang Dasar ini." 
Jie, Hakim Lie Oen Hock memperhatikan aturan peralihan dan menjatuhkan putusan setelah terlebih dahulu mempertimbangkan Kitab Undang-Undang Hukum Perdata, hukum Islam, dan hukum nasional dari penggugat yang berkewarganegaraan Republik Rakyat Cina. ${ }^{49}$ Instruksi Presidium Kabinet No. 31/U/ IN/12/1966, yang menginstruksikan Kantor Catatan Sipil untuk membuka pendaftaran untuk semua penduduk tanpa mengindahkan golongan rakyat, tidak menghapuskan golongan rakyat dari zaman kolonial. ${ }^{50}$ Menurut penulis, golongan rakyat, yang merupakan struktur sosial kolonialisme, demi hukum berakhir oleh Proklamasi. Setelah itu, golongan rakyat berubah menjadi golongan hukum (groepsrecht), sehingga pluralisme tetap berlangsung dan terhindarilah kekosongan hukum. ${ }^{51}$

Sejak awal Kemerdekaan pembentukan hukum nasional sudah menyita perhatian banyak sarjana hukum. Tidak kurang dari adisarjana Supomo, ${ }^{52}$ Notaris Mr. Suwandi,,53 Hakim Agung Sutan Kali Malikul Adil, ${ }^{54}$ advokatcum-yuris Sudargo Gautama, ${ }^{55}$ Ko Tjay Sing,, ${ }^{56}$ sampai Oey Pek Hong ${ }^{57}$ mencurahkan pikiran mereka untuk pembaharuan hukum nasional. Analisis mereka semua berangkat dari titik yang sama: perlunya pembaharuan (sistem) hukum nasional Indonesia. Namun upaya ini belum kunjung membuahkan hasil yang diharapkan. Tiadanya model rujukan yang dapat disetujui bersama oleh para sarjana merupakan kendala abadi bagi pembentukan hukum nasional. ${ }^{58}$

Awalnya wacana pembentukan hukum nasional berkutat pada dua jenis perdebatan yang saling bersinggungan. ${ }^{59}$ Pertama adalah perdebatan antara unifikasi dan harmonisasi hukum. ${ }^{60}$ Jalan tengah dari perdebatan ini adalah pendikotomian isu hukum. ${ }^{61}$ Harmonisasi hukum adalah pendekatan yang ditempuh isu

49 Putusan Pengadilan Negeri Jakarta, No. 373/1952 G, 5 Desember 1953. Lie Oen Hock kemudian menjadi guru besar luar biasa untuk Pengantar Ilmu Hukum dan Tata Hukum Indonesia di Universitas Indonesia sejak tahun 1959.

50 Bdk. Sudargo Gautama, Hukum Antar Tata Hukum: Kumpulan Karangan (Bandung: Alumni, 1977), hlm. 47.

$51 \quad$ Ibid., hlm. 221. Lebih lanjut, lih. Oppusunggu, Disertasi, hlm. 24-45.

52 Supomo, Kedudukan Hukum Adat di Kemudian Hari, orasi ilmiah pada dies natalies Universitas Gajah Mada, 17 Maret 1947, (Yogyakarta: Universitas Gajah Mada, 1947). Lih. juga Supomo, "Hukum Adat di Kemudian Hari Berhubung dengan Pembinaan Negara Indonesia", Hukum - Madjallah Perhimpunan Ahli-Hukum Indonesia, 4-5 (1952): 3-18.

53 Suwandi menyerukan perlunya kodifikasi hukum nasional. Lih. Subekti, Bunga Rampai Ilmu Hukum (Bandung: Alumni, 1983), hlm. 59.

54 St. K. Malikul Adil, Pembaharuan Hukum Perdata Kita (Jakarta: Pembangunan, 1955).

55 Lih. Gautama, Pembaharuan.

56 Ko Tjay Sing, Kodifikasi dan Unifikasi Hukum Perdata dan Dagang (Semarang: Fakultas Hukum dan Pengetahuan Masyarakat Universitas Semarang, 1958).

57 Oey Pek Hong, Peranan Kodifikasi, Jurisprudensi dan Ilmu Pengetahuan dalam Perkembangan Hukum Perdata, pidato pengukuhan guru besar (Surabaya: Fakultas Hukum Universitas Airlangga, 1959).

58 Adisarjana Djokosoetono, misalnya, menyesalkan tidak tercatatnya peraturan pada zaman Majapahit yang mungkin bisa menjadi dasar hukum nasional. Lih. Slametmuljana, Perundang-undangan Madjapahit (Jakarta: Bhratara, 1967), hlm. 18.

59 Selanjutnya perdebatan ini bersifat laten.

60 ASEAN Law Association, ASEAN Legal System (Singapore: Butterworths Asia, 1995), hlm. 52. Ini merupakan pengulangan dari perdebatan antara Mazhab Leiden v. Mazhab Utrecht di awal abad ke-20. Peter Burns, Concept of Law in Indonesia (Leiden: KITLV Press, 2004), hlm. 77-89.

61 C. F. G. Sunaryati Hartono, Bhinneka Tunggal Ika sebagai Asas Hukum bagi Pembangunan Hukum Nasional (Bandung: Citra Aditya Bakti, 2006), hlm. 11-16. 
hukum sensitif, terutama terkait dengan hukum keluarga. Unifikasi hukum adalah pendekatan untuk isu hukum netral, seperti hukum perjanjian dan dagang. Perdebatan kedua adalah hukum apakah yang akan menjadi dasar hukum nasional. Puak hukum adat berpendapat bahwa hukum nasional haruslah berakar, berangkat dan diangkat dari hukum rakyat yang ada, yakni hukum adat. ${ }^{62}$ Mereka yang oposan berpendapat bahwa hukum adat tidak saja menghambat upaya unifikasi hukum, tapi juga perkembangan bangsa Indonesia. ${ }^{63}$ Terlepas dari pendapat oposan ini, dalam perjalanannya ketentuan-ketentuan hukum adat tetap diperhatikan dalam upaya pembentukan hukum perjanjian nasional. ${ }^{64}$

Melihat realita tersebut, Gautama dengan lantang menyatakan arah perkembangan hukum Indonesia tetap akan berpijak pada pluralisme hukum. ${ }^{65}$ Seiring dengan gencarnya Indonesia menarik modal asing, Gautama kemudian memprediksi perkembangan HATAH Ekstern (Hukum Perdata Internasional) akan lebih dominan ketimbang HATAH Intern. ${ }^{66}$ Sunaryati Hartono juga melihat tren yang sama dalam perkembangan hukum nasional, namun berpijak pada hukum antaradat. ${ }^{67}$ Meski kemudian beliau berubah pikiran, pandangannya tentang pluralisme hukum tidak berubah.

Terbukanya Indonesia untuk modal asing pasca terbitnya Undang-Undang Penanaman Modal Asing68 berdampak besar pada perkembangan hukum nasional. Para investor asing berpendapat bahwa hukum Indonesia tidak kompatibel perkembangan kebutuhan kegiatan ekonomi. ${ }^{69} \mathrm{Hal}$ ini kemudian mendorong serangkaian reformasi hukum untuk menjawab kebutuhan investor asing. ${ }^{70}$ Rangkaian ini diawali dengan Survey of Indonesian Economic Law pada awal dekade 1970-an yang dilakukan oleh Fakultas Hukum Universitas Padjadjaran. ${ }^{71}$ Dua puluh tahun kemudian usaha mereformasi hukum Indonesia terus berlanjut antara lain lewat Economic Law and Improved Procurement System (ELIPS) Project yang dilakukan oleh Fakultas Hukum Universitas Indonesia. ${ }^{72}$ Salah

62 Soetandyo Wignjosoebroto, Dari Hukum Kolonial ke Hukum Nasional: Suatu Kajian tentang Dinamika SosialPolitik dalam Perkembangan Hukum Selama Satu Setengah Abad di Indonesia, 1840-1990 (Jakarta: RajaGrafindo Persada, 1994), hlm. 237-240.

63 St. Takdir Alisjahbana, Indonesia in the Modern World (New Delhi: Congress for Cultural Freedom, 1961), hlm. 100-109.

64 Lih. Gautama, Pembaharuan, hlm. 29-32. Undang-Undang No. 5 Tahun 1960 tentang Peraturan Dasar Pokokpokok Agraria, LNRI 1960-104, sebagai contoh, menggunakan konsep-konsep hukum adat. Demikian juga halnya dengan perjanjian bagi hasil (production sharing contract) di bidang minyak dan gas.

65 Gouw Giok Siong, Hukum Antargolongan Hukum yang Hidup! Pidato pengukuhan guru besar luar biasa dalam ilmu hukum perselisihan, 27 September 1958 (Jakarta: Fakultas Hukum dan Pengetahuan Masyarakat Universitas Indonesia).

66 Gautama, Pengantar, hlm. 23-24.

67 Sunaryati Hartono, Dari Hukum Antar Golongan ke Hukum Antar Adat (Bandung: Citra Aditya Bakti, 1991), hlm. 21-33.

68 Undang-Undang No. 1 Tahun 1967 tentang Penanaman Modal Asing. LNRI 1967-1, TLNRI 2818.

69 Demikianlah salah satu kesimpulan dari The Indonesian Investment Conference di Jenewa, yang diprakarsai oleh James A. Linen, presiden direktur Time Inc. Lih. John H. Sullivan, The United States and the 'New Order' in Indonesia, disertasi (Washington D. C.: American University, 1969).

70 Sumantoro, Problems of Investment in Equities and in Securities (Jakarta: Binacipta, 1984), hlm. 437-444.

71 Survei ini mencakup bidang hukum bisnis, pajak, ketenagakerjaan, pertambangan, dan agraria. International Legal Center, yang berkedudukan di New York, menjadi donatur utama survei ini.

72 Donatur utama ELIPS Project adalah United States Agency for International Development. 
satu hasil dari ELIPS Project adalah UndangUndang Perseroan Terbatas (1995). ${ }^{73}$ Tekanan untuk terus mereformasi hukum nasional bertambah setelah Indonesia meratifikasi Persetujuan Pendirian Organisasi Perdagangan Dunia. ${ }^{74}$ Sebelum Krisis Moneter melanda, dibantu oleh Bank Dunia Badan Perancang Pembangunan Nasional telah mengadakan Diagnostic Assessment of Legal Development in Indonesia untuk menyesuaikan lebih lanjut hukum nasional dengan pembangunan ekonomi.

Perkembangan di atas menunjukkan kebenaran prediksi Gautama tentang dominannyaHATAHEksterndalampembangunan hukum nasional. Ironisnya, perkembangan tersebut tidak dipayungi oleh undang-undang tentang hukum perdata internasional. Upaya untuk menyusun Rancangan Undang-Undang Hukum Perdata Internasional telah dirintis sejak awal 1980-an dengan Gautama sebagai ketua. ${ }^{75}$ Rancangan Undang-Undang tersebut telah direvisi seperlunya pada tahun 1997/1998. ${ }^{76}$ Namun Rancangan Undang-Undang tersebut tidak kunjung mendapatkan persetujuan Dewan
Perwakilan Rakyat. Upaya terakhir terjadi pada tahun 2015, ketika Badan Pembinaan Hukum Nasional kembali menyiapkan Naskah Akademik Rancangan Undang-Undang Hukum Perdata Internasional. ${ }^{77}$ Namun hingga saat ini, Indonesia tidak kunjung mempunyai suatu Undang-Undang Hukum Perdata Internasional.

Di sisi lain, kita menyaksikan bahwa HATAH Intern mengalami perkembangan signifikan pasca-Reformasi. Di ujung Timur Nusantara, peran pengadilan adat mendapatkan pengakuan negara dalam penyelesaian sengketa. ${ }^{78}$ Sementara itu, di ujung Barat, menyimpangi ketentuan prinsip nasionalitas, hukum yang berlaku bagi seorang Muslim yang berada di Aceh adalah hukum Islam. ${ }^{79}$ Meski lebih dari empat dekade yang lalu Undang-Undang Perkawinan berhasil menyatukan pengaturan dalam satu kitab, namun peraturan tentang perkawinan tetap bersifat plural. ${ }^{80}$

Bila pluralisme hukum tentang pribadi kodrati terus berlangsung, hukum yang berlaku untuk badan hukum mengalami unifikasi. Penyederhanaan, pertama-tama, terjadi karena pada praktiknya WNI yang berasal dari

73 Sudargo Gautama, Komentar atas Undang-Undang Perseroan Terbatas (Baru) Tahun 1995 No. 1 Perbandingan dengan Peraturan Lama (Bandung: Citra Aditya Bakti, 1995), hlm. 2.

74 Undang-Undang No. 7 Tahun 1994 tentang Pengesahan Agreement Establishing the World Trade Organization, LNRI 1994-57, TLNRI 57.

75 Badan Pembinaan Hukum Nasional, Lokakarya Hukum Perdata Internasional (Jakarta: Badan Pembinaan Hukum Nasional, 1984).

76 Sepanjang pengetahuan penulis, versi RUU HPI 1997/1998 yang dikeluarkan oleh Departemen Kehakiman (sekarang Kementerian Hukum dan HAM) adalah versi terakhir.

77 Penulis menjadi salah seorang anggota tim penyusun. Naskah dapat diakses di https://www.bphn.go.id/data/ documents/na_ruu_ttg_hukum_perdata_internasional_(lanjutan).pdf

78 Pasal 50-51 Undang-Undang No. 21 Tahun 2001 tentang Otonomi Khusus bagi Provinsi Papua, LNRI 2001135, LNRI 4151 sebagaimana diubah oleh Undang-Undang No. 35 Tahun 2008 tentang Penetapan Peraturan Pemerintah Pengganti Undang-Undang No. 1 Tahun 2008 tentang Perubahan Undang-Undang No. 21 Tahun 2001 tentang Otonomi Khusus bagi Provinsi Papua Menjadi Undang-Undang, LNRI 2008-112, TLNRI 4884.

79 Pasal 126:1 jo. Pasal 128:2 Undang-Undang No. 11 Tahun 2006 tentang Pemerintahan Aceh, LNRI 2006-62, TLNRI 4633.

80 Periksa pasal 2:1 Undang-Undang No. 1 Tahun 1974 tentang Perkawinan, LNRI 1974-1, TLNRI 3019, mengatur bahwa, "Perkawinan adalah sah, apalagi dilakukan menurut hukum masing-masing agamanya dan kepercayaannya itu." Kursif oleh penulis. 
golongan hukum non-Kitab Undang-Undang Hukum Perdata memilih untuk menundukkan diri dengan mendirikan NV (baca: PT) ${ }^{81}$ Tidak jelas apa yang menjadi alasan pemilihan NV ketimbang IMA. ${ }^{82}$ Secara hukum, keberlakuan Undang-Undang Perseroan Terbatas (1995) mengakhiri dualisme bentuk badan hukum. ${ }^{83}$

Berdasarkan sejarah dan perkembangan hukum nasional yang ada, maka dapatlah ditarik kesimpulan bahwa pluralisme hukum merupakan conditio sine qua non bagi bangsa Indonesia. Dengan demikian, benarlah pendapat Sunaryati Hartono yang mengidentifikasi bhineka tunggal ikal sebagai asas hukum bagi pembangunan hukum nasional.

\section{Perjanjian-Perjanjian Internasional Sebagai Bagian dari HATAH}

Untuk menarik modal asing, hukum Indonesia harus mampu memberikan kepastian hukum dalam berusaha, dan mengikuti hukum yang berkembang di dunia internasional. Umumnya yang dimaksud dengan yang terakhir adalah perjanjian internasional atau konvensikonvensi. Pembaharuan hukum, modernisasi hukum, pembinaan hukum, pembangunan hukum, reformasi hukum, atau apapun label yang diberikan kepada perubahan hukum adalah upaya yang bertujuan memutakhirkan hukum
Indonesia. Dalam pemutakhiran tersebut juga terdapat masalah budaya hukum, dan ideologi.

Salah satu permasalahan utama dalam hukum Indonesia adalah dominannya bentuk perseroan terbatas dalam perekonomian. Apakah perseroan terbatas, yang notabene merupakan persekutuan modal, mampu untuk bergotong-royong dalam mewujudkan kemakmuran rakyat sebagaimana dituntut oleh pasal 33 ayat (1) Undang-Undang Dasar Negara Republik Indonesia Tahun 1945?

Arsitek ekonomi Indonesia merdeka, Mohammad Hatta, memberikan analisis sosialekonomi dan hukum terkait dengan pencapaian kemakmuran rakyat. $^{84}$ Secara konsisten Hatta menunjuk kooperasi sebagai wahana untuk mencapai "kemakmuran rakyat". ${ }^{85}$ Karakteristik utama dari kooperasi adalah gotong-royong, yang selaras dengan asas kekeluargaan. Berbeda dengan Hatta, Purwosutjipto berpendapat kooperasi adalah kerja sama antara orangorang yang tidak bermodal untuk mencapai kemakmuran bersama. ${ }^{86}$ Kegotong-royongan adalah antinomi individualisme.

Dalam pengurusan perseroan terbatas, kegotong-royongan/individualisme ini tercermin dalam pemungutan suara. Pengaturan pemungutan suara dalam perseroan terbatas mengalami perubahan. Pasal 54 Kitab Undang-

81 Yu Un Oppusunggu et al., Naskah Akademik Rancangan Undang-Undang tentang Perseroan Terbatas (Jakarta: Badan Pembinaan Hukum Nasional, 2016), hlm. 25-26. Lih. juga Yu Un Oppusunggu, "Mandatory Corporate Social and Environment Responsibility in the New Indonesian Limited Liability Law," Indonesian Law Review I (2011): 73-74.

82 Lih. misalnya Nono Anwar Makarim, Mengada-ada Perseroan Terbatas (Jakarta: Pusat Studi Hukum dan Ekonomi, Fakultas Hukum Universitas Indonesia, 1977), hlm. 18-19.

83 Pasal 128:3 Undang-Undang No. 1 Tahun 1995 tentang Perseroan Terbatas, LNRI 1995-13, TLNRI 3587.

84 Mohammad Hatta, Lampau dan Datang, pidato penerimaan doctor honoris causa dari Universitas Gajah Mada (Yogyakarta: Universitas Gajah Mada, 1956), hlm. 34-39.

85 Mohammad Hatta et al., Penjabaran Pasal 33 UUD 1945 (Jakarta: Mutiara, 1977), hlm. 26-33.

86 H. M. N. Purwosutjipto, Pengertian Hukum Dagang Indonesia 2: Bentuk-bentuk Perusahaan (Jakarta: Djambatan, 1995), hlm. 183. 
Undang Hukum Dagang awalnya mengatur sebagai berikut:

"Dalam akta harus diatur pula dengan cara bagaimana hak suara oleh para pesero harus digunakan. Dalam pada itu, jika perseroan itu terdiri atas paling sedikitnya seratur sero atau andil, maka tiap-tiap satu orang untuk diri sendiri tidak boleh mengeluarkan lebih dari enam suara, sedangkan jika jumlah tadi kurang dari itu, tidak boleh lebih dari tiga suara."

Rasio ketentuan di atas adalah untuk mencegah terkumpulnya suara dalam satu tangan. ${ }^{87}$ Pasal I Undang-Undang No. 4 Tahun 1971 mengubah dan menambah sehingga pasal 54 Kitab Undang-Undang Hukum Dagang menjadi sebagai berikut: ${ }^{88}$

"(1)Hanya pemegang saham yang berhak mengeluarkan suara. Setiap pemegang saham sekurang-kurangnya berhak mengeluarkan satu suara.

(2) Dalam hal modal perseroan terbagi dalam saham-saham dengan harga nominal yang sama, maka setiap pemegang saham berhak mengeluarkan suara sebanyak jumlah saham yang dimilikinya.

(3) Dalam hal modal perseroan terbagi dalam saham-saham dengan harga nominal yang berbeda, maka setiap pemegang saham berhak mengeluarkan suara sebanyak kelipatan dari harga nominal saham yang terkecil dari perseroan terhadap keseluruhan jumlah harga nominal dari saham yang dimiliki pemegangnya. Sisa suara yang belum mencapai satu suara tidak diperhitungkan.

(4) Pembatasan mengenai banyaknya suara yang berhak dikeluarkan oleh pemegang saham dapat diatur dalam akta pendirian, dengan ketentuan bahwa seorang pemegang saham tidak dapat mengeluarkan lebih dari enam suara apabila modal perseroan terbagi dalam seratus saham atau lebih, dan tidak dapat mengeluarkan lebih dari tiga suara apabila modal perseroan terbagi dalam kurang dari seratus saham."

Pengubahan ketentuan tersebut membuat pasal 54 Kitab Undang-Undang Hukum Dagang dari monosistem menjadi dwisistem: sistem hak suara terbatas dan sistem hak suara tak terbatas. Sistem terbatas, sebagaimana dianut oleh ketentuan asli, diatur dalam ayat (4). Sistem tak terbatas diatur dalam ayat (1)(3). Penambahan sistem hak suara ini erat hubungannya dengan lahirnya Undang-Undang Penanaman Modal Asing, yang menunjukkan sikap Pemerintah Orde Baru terhadap modal asing. ${ }^{89}$ Dalam keterangannya kepada, waktu itu, DPR-GR, Pemerintah menyatakan bahwa sistem hak suara terbatas merupakan hambatan dalam melancarkan pengerahan dana masyarakat. ${ }^{90}$

Undang-Undang Perseroan Terbatas (1995) memberikan kemungkinan untuk mengesampingkan prinsip one share one vote dari sistem hak suara terbatas maupun tak terbatas dari pasal 54 Kitab Undang-Undang Hukum Dagang. Pasal 72 ayat (1) UndangUndang Perseroan Terbatas (1995) mengatur: "Setiap saham yang dikeluarkan mempunyai satu hak suara, kecuali Anggaran Dasar menentukan lain." Pasal 84 ayat (1) UndangUndang Perseroan Terbatas (2007) mengambilalih pengaturan ini secara verbatim. Saham tanpa hak suara ini adalah konsekuensi dari pengklasifikasian saham perseroan terbatas..$^{91}$

\section{Ibid., hlm. 131.}

88 Undang-Undang No. 4 Tahun 1971 tentang Perubahan dan Penambahan atas Ketentuan Pasal 54 Kitab UndangUndang Hukum Dagang (S. 1847-23), LNRI 1971-20.

89 Lih. butir "Memperhatikan", dan alinea ketiga dari Penjelasan Umum dari Undang-Undang No. 4 Tahun 1971.

90 Purwosutjipto, hlm. 134.

91 Lih. pasal 46 ayat (1) UU Perseroan Terbatas (1995), dan pasal 53 ayat (1) Undang-Undang No. 40 Tahun 2007 tentang Perseroan Terbatas, LNRI 2007-106, LNRI 4756. 
Di samping pengaturan hak suara - one share one vote - yang tidak sesuai dengan prinsip kebersamaan, kita dapat menemukan permasalahan budaya hukum dalam praktik perseroan terbatas. Dalam banyak kasus, kita temukan bahwa perseroan terbatas yang merupakan kumpulan modal dijalankan tidak lebih daripada perusahaan keluarga. Perseroan terbatas tidak menjadi subjek hukum yang terpisah dari pemegang saham, melainkan halnya sekedar alter ego yang diadakan untuk kepentingan dagang. ${ }^{92}$

Undang-Undang Penanaman Modal mendorong perubahan pesat hukum ekonomi, yakni hukum yang mengatur tentang kegiatan dagang. Perkembangan pesat terjadi dengan ikut sertanya Indonesia dalam sejumlah konvensi. Untuk penyelesaian sengketa yang bersifat independen dengan invenstor asing, Indonesia ikut serta dalam Convention on the Establishment of the International Center for Settlement of Investment Disputes between States and Nationals of Other States (Konvensi ICSID). ${ }^{93}$ Untuk pengakuan putusan arbitrase asing yang menyelesaikan sengketa perdagangan, Indonesia mengesahkan Convention on the Recognition and Enforcement of Foreign Arbitral Awards (Konvensi New
York). ${ }^{94}$ Untuk menjamin investor asing dari risiko non-komersial, Indonesia mengesahkan Convention Establishing the Multilateral Investment Guarantee Agency. ${ }^{95}$

Pelaksanaan Konvensi New York menimbulkan banyak permasalahan. Awalnya permasalahan berkisar pada perbedaan pendapat tentang perlu tidaknya peraturan pelaksana. ${ }^{96}$ Permasalahan tersebut teratasi setelah keluar Peraturan Mahkamah Agung No. 1 Tahun 1990 tentang Tata Cara Pelaksanaan Putusan Arbitrase Asing. Permasalahan kemudian bergeser pada batasan ketertiban umum pelaksanaan putusan asing. ${ }^{97}$ Apakah yang merupakan ketertiban umum hukum Indonesia membutuhkan suatu kecermatan dan kebijaksanaan analisis tentang hukum nasional dengan menerapkan Hukum Perdata Internasional Indonesia tanpa mengabaikan aspek-aspek fundamental dari HATAH Intern. ${ }^{98}$ Namun hal yang patut disesalkan, yurisprudensi menunjukkan ketidakkonsistenan persepsi pengadilan tentang ketertiban umum hukum nasional. ${ }^{99}$ Ketidakkonsistenan ini tidak dapat diatasi oleh Undang-Undang Arbitrase. ${ }^{100}$

Dalam pengaturan hak cipta kita juga dapat menemukan permasalahan hukum terkait dengan HATAH. Hukum positif Indonesia

92 Oppusunggu et al., Naskah Akademik Rancangan Undang-Undang tentang Perseroan Terbatas (Jakarta: Badan Pembinaan Hukum Nasional, 2016), hlm. 22-23.

93 Undang-Undang No. 5 Tahun 1968 tentang Persetujuan atas Konvensi tentang Penyelesaian Perselisihan antara Negara dan Warga Negara Asing mengenai Penanaman Modal, LNRI 1968-32, TLNRI 2852.

94 Keputusan Presiden No. 34 Tahun 1981, LNRI 1981-40 tentang Pengesahan Convention on the Recognition and Enforcement of Foreign Arbitral Awards.

95 Keputusan Presiden Indonesia No. 31 Tahun 1986 tentang Pengesahan Convention Establishing the Multilateral Investment Guarantee Agency, LNRI 1986-45.

96 Navigation Maritime Bulgare (Bulgaria) v. PT Nizwar, Putusan Mahkamah Agung No. 2944 K/Pdt/1983, sebagaimana termuat dalam Varia Peradilan 18 (1987).

97 Oppusunggu, Disertasi, hlm. 190-199.

98 Ibid., hlm. 116-166.

98 E. D. \& F. MAN (Sugar) v. Yani Haryanto, Putusan Mahkamah Agung No. 12 K/Pdt/1990, putusan Mahkamah ${ }^{98}$ Agung No. 12 K/Pdt/1990, sebagaimana terdapat dalam Sudargo Gautama, Landmark Decisions, Jilid 3 (Bandung: Alumni, 1993).

100 Undang-Undang No. 30 Tahun 1999 tentang Arbitrase dan Penyelesaian Sengketa, LNRI 1999-138, TLNRI 3872. 
untuk hak cipta adalah Undang-Undang Hak Cipta (2014). ${ }^{101}$ Undang-Undang ini mencabut Undang-Undang Hak Cipta (2002). ${ }^{102}$ UndangUndang yang disebut terakhir terlebih dahulu mencabut Undang-Undang Hak Cipta (1982). ${ }^{103}$ Sebelum dicabut, Undang-Undang Hak Cipta (1982) telah dua kali berubah. ${ }^{104}$ Pengubahanpengubahan ini tidak lepas dari desakan pihak asing, terutama Amerika Serikat dan Uni Eropa. ${ }^{105}$ Undang-Undang Hak Cipta (1982) mencabut Auteurswet (1912). ${ }^{106}$

Undang-Undang Hak Cipta (1997) ditetapkan dan berlaku secara berbarengan, yakni 7 Mei 1997, dengan keikutsertaan kembali Indonesia di Berne Convention for the Protection of Literary and Artistic Works. ${ }^{107}$ Keberlakuan pasal 1-21 serta Lampiran Konvensi Berne adalah wajib menurut pasal 9 ayat (1) Persetujuan tentang Aspek-aspek Dagang dari Hak Kekayaan Intelektual (Agreement on Trade-related Aspects of Intellectual Property Rights). TRIPs merupakan
Lampiran 1C dari Persetujuan Pembentukan Organisasi Perdagangan Dunia (Agreement Establishing the World Trade Organization), dan mengikat semua negara anggota. ${ }^{108}$ Sebagai negara berkembang, Indonesia mempunyai kewajiban untuk menyesuaikan peraturan nasional terkait hak cipta sampai awal tahun $2000 . .^{109}$

Sebelum era perdagangan bebas, Konvensi Berne pernah berlaku untuk Indonesia. Keberlakuan ini adalah warisan dari Hindia Belanda. Auteurswet terbit sebagai persiapan Belanda untuk menjadi anggota Konvensi Berne. ${ }^{110}$ Ketika menandatangani Konvensi Berne, Belanda mengikutsertakan Hindia Belanda. Per 1 Agustus 1931, Konvensi Berne berlaku untuk Hindia Belanda. ${ }^{111}$ Sesuai dengan Pasal II Aturan Peralihan UUD 1945 (Naskah Asli), Konvensi Berne terus berlaku untuk Indonesia. Selain itu keberlakuan Konvensi Berne adalah sesuai dengan pasal 5 Persetujuan Peralihan

101 Undang-Undang No. 28 Tahun 2014 tentang Hak Cipta, LNRI 2014-266, TLNRI 5599.

102 Undang-Undang No. 19 Tahun 2002 tentang Hak Cipta, LNRI 2002-85, TLNRI 4220.

103 Undang-Undang No. 6 Tahun 1982 tentang Hak Cipta, LNRI 1982-15, TLNRI 3217.

104 Berurut-turut Undang-Undang No. 7 Tahun 1987 tentang Perubahan atas Undang-Undang No. 6 Tahun 1982 tentang Hak Cipta, LNRI 1987-42, TLNRI 3362, dan Undang-Undang No. 12 Tahun 1997 tentang Perubahan atas Undang-Undang No. 6 Tahun 1982 tentang Hak Cipta Sebagaimana Telah Diubah dengan Undang-Undang No. 7 Tahun 1987, LNRI 1997-29, TLNRI 2679.

105 Sudargo Gautama dan Rizawanto Winata, Pembaharuan Undang-Undang Hak Cipta (1997) (Bandung: Citra Aditya Bakti, 1997), hlm. 1. Sebelumnya Indonesia telah menandatangani perjanjian bilateral dengan Masyarakat Ekonomi Eropa untuk rekaman suara (1988), dan dengan Amerika Serikat untuk hak cipta (1989). Lih. Sudargo Gautama, Indonesian Business Law (Bandung: Citra Aditya Bakti, 2006), hlm. 709.

106 Pasal 39, 43, dan 44 tidak berlaku untuk Indonesia.

107 Keputusan Presiden No. 18 Tahun 1997 tentang Pengesahan Berne Convention for the Protection of Literary and Artistic Works, LNRI 1997-35.

108 Pasal II ayat (2) Persetujuan Pembentukan Organisasi Perdagangan Dunia (Agreement Establishing the World Trade Organization).

109 Pasal 65 ayat (2) TRIPs memberikan toleransi selama empat tahun kepada negara berkembang untuk tidak memberlakukan ketentuan-ketentuan yang ada. Indonesia meratifikasi Persetujuan Pembentukan Organisasi Perdagangan Dunia melalui Undang Undang No. 7 Tahun 1994 tentang Pengesahan Agreement Establishing the World Trade Organization (Persetujuan Pembentukan Organisasi Perdagangan Dunia), LNRI 1994-57.

110 Auteurswet [Undang-Undang Pencipta], S. 1912-600 mulai berlaku pada 22 September 1912. Belanda bergabung dengan Konvensi Berne secara aksesi pada 9 Oktober 1912.

111 Bepaling dat de in 1928 te Rome gesloten Herziene Berner Conventie ter bescherming van letterkundige- en kunstwerken op 1 Augustus 1931 voor Nederlandsch-Indië van kracht wordt [Penetapan tentang Konvensi Berne untuk Perlindungan Karya Sastra dan Senin, yang dibuat di Roma pada 1928, akan berlaku pada 1 Agustus 1931 untuk Hindia Belanda], S. 1931-325. 
Perpindahan yang dicapai dalam Konferensi Meja Bundar antara Indonesia dan Belanda. ${ }^{112}$

Namun rupanya Sekretariat Biro Internasional, yang bertanggung jawab atas administrasi, tidak berpandangan bahwa Konvensi Berne akan terus berlaku untuk Indonesia. Dalam Piagam Revisi berdasarkan kesepakatan Brussel, 26 Juni 1948, nama Indonesia terhapus dari daftar anggota. ${ }^{113}$ Akibatnya, terlepas dari aturan peralihan di atas, keterikatan Indonesia pada konvensi ini diragukan. Keragu-raguan tersebut berakhir setelah Perdana Menteri Kabinet Karya, Djuanda, pada tahun 1958 menyatakan Indonesia tidak ikut serta dalam Konvensi Berne.

Alasan-alasan Kabinet Karya untuk tidak ikut serta dalam Konvensi Berne adalah: ${ }^{114}$

"1. Bahwa pada waktu ini di Indonesia banyak terdapat hal-hal yang sebenarnya merupakan pelanggaran hak cipta. Demi kepentingan masyarakat untuk pembangunan negara, tidak sedikit buku-buku asing dipergunakan, baik di sekolah-sekolah maupun di masyarakat. Keanggotaan Indonesia membuka kesempatan kepada pihak yang bersangkutan di luar negeri untuk melancarkan tuntutan terhadap negara kita dan/atau perseorangan atas pelanggaran tadi.

2. Alasan lain ialah, bahwa untuk sesuatu negara, adalah tidak layak untuk masuk persetujuan internasional, sebelum mempunyai undang-undang hak cipta nasional.

3. Segi lain yang perlu diperhatikan adalah, bahwa Pemerintah Belanda telah menunjuk Irian Barat sebagai
Hindia Belanda dulu. Dengan demikian keanggotaan Indonesia dalam [Konvensi Berne] dapat dianggap sebagai pengakuan terhadap Belanda atas Irian Barat, suatu hal yang bertentangan dengan perjuangan kita. Dengan demikian Indonesia tidak menjadi anggota [Konvensi Berne].

4. Tak dapat disangkal tentu ada alasanalasan lain untuk mempertahankan keanggotaan [Konvensi Berne] itu, misalnya supaya hak cipta pengarangpengarang kita dapat perlindungan di luar negeri, akan tetapi bagaimana pun juga kerugian ini tidak mengimbangi keuntungan-keuntungan karena kita tidak masuk persetujuan internasional ini."

Alasan nomor 2 di atas secara tegas menunjukkan aspirasi pembinaan hukum, dan kesadaran bahwa Auteurswet tidak bersifat "nasional". "Undang-undang hak cipta nasional" seyogianya mengutamakan kepentingan nasional. Rancangan Undang-Undang Hak Cipta (1965), misalnya, mengatur sebagai berikut:

Pasal 13

(1) Dengan mengindahkan ketentuanketentuan dalam persetujuanpersetujuan internasional antara Republik Indonesia dengan pihak ketiga, maka untuk kepentingan nasional tidaklah dianggap sebagai pelanggaran hak cipta atas sesuatu ciptaan, tiap terjemahan langsung dan saduran langsung dari bahasa asing ke dalam bahasa Indonesia atau bahasa daerah dengan ketentuanketentuan sebagai berikut:

112 Keputusan Presiden Republik Indonesia Serikat No. 33 Tahun 1950 tentang Pengumuman Dokumen-dokumen Konferensi Meja Bundar, LNRIS 1950-2. Tentang keraguan atas keberlakuan Konvensi Berne, lih. Ajip Rosidi, Undang-Undang Hak Cipta 1982: Pandangan Seorang Awam (Jakarta: Djambatan, 1984), hlm. 8.

113 J. C. T. Simorangkir, Pembinaan Hukum bagi Masyarakat Indonesia (Jakarta: Badan Pembinaan Hukum Nasional, 1980), hlm. 50.

114 Demikian dinyatakan oleh Mr. A. W. Djumena dalam Majalah Pewarta (Oktober 1958), hlm. 12 sebagaimana dikutip oleh Simorangkir, hal. 53. Bdk. Sudargo Gautama, "Indonesia dan Konvensi-konvensi tentang Hak Cipta," Majalah Fakultas Hukum Universitas Indonesia, 3 (1975): 181-183. 
a. Ciptaan asing itu selama dua tahun sejak diterbitkannya belum pernah diterjemahkan ke dalam bahasa Indonesia atau bahasa daerah;

b. Penerjemah telah meminta izin terjemahan dari pemegang hak cipta, tetapi izin itu tidak diperoleh dalam waktu satu tahun sejak permohonan diajukan.

(2) $\ldots$

(3) Menteri ... menetapkan ganti-rugi yang layak kepada pemegang hak cipta dan dalam memberi izin untuk penerjemahan atau penyaduran langsung itu mengindahkan pendapat Biro Hak Cipta. ${ }^{115}$

Penjelasan pasal ini menyatakan bahwa "Pemberian izin dengan syarat-syarat yang terlalu berat, dianggap sebagai penolakan."

Selanjutnya:

Pasal 14

Tanpa mengurangi hak pemegang cipta atas ganti rugi yang layak, jika dianggap perlu untuk kepentingan nasional, karyakarya ciptaan asing dapat diperbanyak untuk keperluan pemakaian dalam wilayah Republik Indonesia, dengan mengindahkan pertimbangan Biro Hak Cipta. ${ }^{116}$

Penjelasan pasal ini menyatakan bahwa “Agar terdapat keseragaman mengenai batasnya kepentingan nasional, harus diminta pertimbangan Biro Hak Cipta." Substansi pengaturan dari kedua pasal di atas, yang tidak ada padanannya di Auteurswet, berhasil menjadi bagian dari Undang-Undang Hak Cipta (1982).

Substansi pengaturan dari kedua pasal di atas, yang tidak ada padanannya di Auteurswet, berhasil menjadi bagian dari Undang-Undang Hak Cipta (1982).
Terjemahan untuk Kepentingan Nasional

Pasal 15

(1) Untuk kepentingan nasional, tiap terjemahan dari ciptaan berbahasa asing ke dalam bahasa Indonesia atau bahasa daerah tidak dianggap sebagai pelanggaran hak cipta dengan ketentuan sebagai berikut:

a. Ciptaan berasal dari negara lain sedikitnya 3 (tiga) tahun sejak diterbitkan belum pernah diterjemahkan ke dalam bahasa Indonesia atau bahasa daerah;

b. Penerjemahan telah meminta izin terjemahan dari pemegang hak cipta, tetapi izin itu tidak diperoleh dalam waktu 1 (satu) tahun sejak permintaan diajukan.

(2) Untuk penerjemahan sebagaimana dimaksud ..., diperlukan izindari Menteri Kehakiman.

(3) Menteri Kehakiman menetapkan imbalan kepada pemegang hak cipta dan dalam memberikan izin untuk penerjemahan itu mendengar pertimbangan Dewan Hak Cipta ....

Perbanyakan untuk Kepentingan Nasional Pasal 16

(1) Dengan mengindahkan ketentuan dalam pasal 48 sub b [tentang karya cipta asing yang diumumkan di Indonesia], maka untuk kepentingan nasional ciptaan orang bukan warga negara Indonesia dan badan asing dapat diperbanyak untuk keperluan pemakaian dalam wilayah Republik Indonesia, dengan ketentuanketentuan sebagai berikut:

a. Ciptaan orang bukan warga negara Indonesia dan badan asing tersebut, selama 2 (dua) tahun sejak diumumkan belum cukup diperbanyak di dalam wilayah Republik Indonesia;

b. Telah dimintakan izin untuk memperbanyak ciptaan tersebut, tetapi izin itu tidak diperoleh

115 Sebagaimana termuat sebagai Lampiran XXIII dalam Simorangkir, hlm. 170-196. Cetak miring oleh penulis.

116 Cetak miring oleh penulis. 
dalam waktu 1 (satu) tahun sejak permintaan diajukan.

(2) Perbanyakan sebagaimana dimaksud ..., tidak dianggap sebagai pelanggaran hak cipta. ${ }^{117}$

Undang-Undang Hak Cipta (1987) mengubah pengaturan kedua pasal ini. Perkataan "kepentingan nasional" untuk pasal 15 dijabarkan menjadi "kepentingan pendidikan, ilmu pengetahuan, dan kegiatan penelitian dan pengembangan". Sedangkan untuk pasal 16, penjabarannya menjadi "kebijaksanaan Pemerintah di bidang pertahanan dan keamanan negara, kesusilaan serta ketertiban umum". Undang-Undang Hak Cipta (1997) tidak mengubah redaksional kedua pasal ini.

Dalam Undang-Undang Hak Cipta (2002) perkataan "kepentingan nasional" tidak hanya mengalami penjabaran lebih lagi, namun juga lebih bias: "kepentingan pendidikan, penelitian, penulisan karya ilmiah, penyusunan laporan, penulisan kritik atau tinjauan suatu masalah"; "keperluan pembelaan di dalam atau di luar Pengadilan"; "tujuan pendidikan dan ilmu pengetahuan"; "pertunjukan atau pementasan yang tidak dipungut bayaran"; "guna keperluan para tunanetra"; 118 "kepentingan pendidikan, ilmu pengetahuan, serta kegiatan penelitian dan pengembangan, terhadap Ciptaan dalam bidang ilmu pengetahuan dan sastra"; ${ }^{119}$ dan "kebijaksanaan Pemerintah di bidang agama, pertahanan dan keamanan negara, kesusilaan serta ketertiban umum". ${ }^{120}$

Undang-Undang Hak Cipta

mempertahankan dan mengubah penjabaran "kepentingan nasional" menjadi "untuk keperluan keamanan serta penyelenggaraan pemerintahan, legislatif, dan peradilan"; "untuk penyandang tuna netra, penyandang kerusakan penglihatan atau keterbatasan dalam membaca, dan/atau huruf braille, buku audio, atau sarana lainnya"; "pertimbangan pelaksanaan teknis" terkait karya arsitektur. ${ }^{121}$

Keanggotaan dalam Organisasi Perdagangan Dunia menuntut hukum nasional selaras dengan kewajiban dan komitmen Indonesia di tingkat internasional. ${ }^{122}$ Kewajiban tersebut bersifat global dan komprehensif. Indonesia, dan setiap anggota Organisasi Perdagangan Dunia, wajib membuat peraturan yang berpijak pada prinsip-prinsip perdagangan internasional, yakni bangsa-bangsa yang paling diutamakan (most-favored nation), dan perlakuan nasional (national treatment). Kedua prinsip ini berasal dari teori-teori hukum perdata internasional tentang timbal-balik dan pembalasan. ${ }^{123}$

\section{Penutup}

Pemaparan di atas menunjukkan bahwa hukum di Indonesia bersifat plural. Pluralisme hukumyangadaterjadikarenaadanya pengakuan dan persamaan perlakuan terhadap hukum-

117 Cetak miring oleh penulis.

118 Pasal 15 ayat (1)-(4) Undang-Undang Hak Cipta (2002).

119 Pasal 16 ayat (1) Undang-Undang Hak Cipta (2002).

120 Pasal 17 Undang-Undang Hak Cipta (2002).

121 Pasal 44 ayat (1)-(3) Undang-Undang Hak Cipta (2014).

122 Artikel XVI:4 Persetujuan Marrakesh tentang Pembentukan Organisasi Perdagangan Dunia mengatur bahwa, "Each Member shall ensure the conformity of its laws, regulations and administrative procedures with its obligations as provided in the annexed Agreements."

123 Sudargo Gautama, Hukum Perdata Internasional Indonesia, Jilid II Bagian 5 (Bandung: Alumni, 1988), hlm. 136171. 
hukum yang ada. Lanskap hukum yang demikian menuntut pemahaman akan HATAH, ilmu yang menganalisis tentang hukum yang berlaku. Pluralisme juga menunjukkan adanya budayabudaya hukum yang berbeda. Kemerdekaan Indonesia dan usaha pembentukan hukum nasional tidak menghapuskan pluralisme tersebut, tapi menghadirkan konteks dan tantangan yang berbeda.

Contoh-contoh perkembangan hukum di bidang perseroan terbatas, penanaman modal, hak cipta, dan perdagangan internasional, menunjukkan adanya benturan antara kepentingan nasional dan komitmen Indonesia kepada dunia internasional. Benturan tersebut membutuhkan kepiawaian dalam ilmu hukum, khususnya HATAH.

Dalam konteks Indonesia, HATAH mempunyai aspek intern dan ekstern. Keduanya berkutat pada pluralisme budaya hukum dan kepentingan yang berbeda. Belum cukupnya perundangundangan nasional, khususnya untuk HATAH Ekstern atau hukum perdata internasional, telah menjadi persoalan tersendiri. Sebagai contoh penulis telah merujuk pada pengakuan dan pelaksanaan putusan arbitrase asing. Sekalipun sudah terdapat peraturan perundang-undangan, masalah HATAH tidak akan selesai. Secara singkat penulis memberikan isu ketertiban umum sebagai contoh. Dalam berbagai kasus ketertiban umum menjadi pertemuan antara kepentingan nasional, seperti pembentukan hukum nasional, dan kepentingan privat, seperti kepastian hukum bagi investor.

Prinsip berpikir dan bertindak yang sesuai dengan kondisi hukum Indonesia sudah digariskan oleh adisarjana Djokosoetono: geordend denken en georded doordenken, berpikir tertib dan berpikir menembus dengan tertib. ${ }^{124}$ Pemaparan singkat di atas hendaknya memberikan pelajaran bahwa kecermatan memahami pluralisme hukum, dan penguasaan ilmu HATAH merupakan keharusan untuk pengembangan hukum nasional di masa depan.

\section{Daftar Pustaka}

\section{Buku}

Adil, St. K. Malikul, Pembaharuan Hukum Perdata Kita (Jakarta: Pembangunan, 1955).

Alisjahbana, St. Takdir, Indonesia in the Modern World (New Delhi: Congress for Cultural Freedom, 1961).

Amin, S. M., Kodifikasi dan Unifikasi Hukum Nasional (Jakarta: Sastra Hudaya, 1978).

ASEAN Law Association, ASEAN Legal System (Singapore: Butterworths Asia, 1995).

Besar, Abdulkadir, "Negara Persatuan" Citanegara Integralistik Anutan UUD 1945", dalam Selo Soemardjan (ed.), Guru Pinandita, Sumbangsih untuk Prof. Djokosoetono, SH (Jakarta: Lembaga Penerbitan Fakultas Ekonomi Universitas Indonesia, 2006).

Burns, Peter, Concept of Law in Indonesia (Leiden: KITLV Press, 2004).

Fasseur, C., "Colonial Dilemma: Van Vollenhoven and the Struggle Between Adat Law and Western Law in Indonesia", dalam W. J. Mommsen dan J. A. de Moor, European Expansion and Law The Encounter and Indigenous Law in 19th-and 20th-Century Africa and Asia (Oxford/New York: Berg, 1992).

Gautama, Sudargo, Pengantar Hukum Perdata Internasional Indonesia (Jakarta: Bina Cipta, 1987).

Gautama, Sudargo, Pembaharuan Hukum di Indonesia (Bandung: Alumni, 1973).

Gautama, Sudargo, Hukum Antar Tata Hukum: Kumpulan Karangan (Bandung: Alumni, 1977).

Gautama, Sudargo, Hukum Perdata Internasional Indonesia, Jilid II Bagian 5 (Bandung: Alumni, 1988).

124 Abdulkadir Besar, "Negara Persatuan" Citanegara Integralistik Anutan UUD 1945”, dalam Soemardjan, Pinandita, hlm. 105. 
Gautama, Sudargo, Hukum Antargolongan: Suatu Pengantar (Jakarta: Ichtiar Baru van Hoeve, 1993).

Gautama, Sudargo, Komentar atas UndangUndang Perseroan Terbatas (Baru) Tahun 1995 No. 1 Perbandingan dengan Peraturan Lama (Bandung: Citra Aditya Bakti, 1995). Indonesian Business Law (Bandung: Citra Aditya Bakti, 2006).

Gautama, Sudargo, "Prof. Djokosoetono dan Hukum Antar Tata Hukum", dalam Selo Soemardjan (ed.), Guru Pinandita, Sumbangsih untuk Prof. Djokosoetono, SH (Jakarta: Lembaga Penerbitan Fakultas Ekonomi Universitas Indonesia, 2006).

Gautama, Sudargo, Warganegara dan Orang Asing (Jakarta: Keng Po, 1958).

Gautama, Sudargo dan Rizawanto Winata, Pembaharuan Undang-Undang Hak Cipta (1997) (Bandung: Citra Aditya Bakti, 1997).

Hartono, Sunaryati, Dari Hukum Antar Golongan ke Hukum Antar Adat (Bandung: Citra Aditya Bakti, 1991).

Hartono, Sunaryati, Bhinneka Tunggal Ika sebagai Asas Hukum bagi Pembangunan Hukum Nasional (Bandung: Citra Aditya Bakti, 2006).

Hatta, Mohammad et al., Penjabaran Pasal 33 UUD 1945 (Jakarta: Mutiara, 1977).

Holleman, J. F. (ed.), Van Vollenhoven on Indonesian Adat Law (Selection from Het Adatrecht van Nederlandsch-Indië (Volume I, 1918; Volume II, 1931) (The Hague: Martinus Nijhoff, 1981).

Kartohadiprodjo, Soediman, Pengantar Tata Hukum di Indonesia (Jakarta: Ghalia Indonesia, 1993).

Kollewijn, R. D., Intergentiel Recht (Bandung: van Hoeve, 1955).

Ko Tjay Sing, Kodifikasi dan Unifikasi Hukum Perdata dan Dagang (Semarang: Fakultas Hukum dan Pengetahuan Masyarakat Universitas Semarang, 1958).

Ko Swan Sik dan Teuku Moh. Rhadie, "Nationality and International Law in Indonesian Perspective", dalam Ko Swan Sik (ed.), Nationality and International Law in Asian Perspective (Dordrecht: Martinus Nijhoff, 1990).

Lemaire, W. L. G., Het Recht in Indonesia (Bandung: Uitgeverij W. van Hoeve, 1955).

Marsden, William, The History of Sumatra, ed. ke-3 (Oxford: Oxford University Press, 1966).

Oppusunggu, Yu Un, “Gautama, Sudargo”, dalam Leo Suryadinata (ed.) Southeast Asian Personalities of Chinese Descent: A Biographical Dictionary
(Singapore: The Chinese Heritage Center, Nanyang Technology University, 2012).

Oppusunggu, Yu Un dan Gary F. Bell, "Indonesia”, dalam Jürgen Basedow, Gissela Ruhl, Franco Ferrari, dan Pedro de Miguel Asensio (eds.), Encyclopedia of Private International Law, Vol. 3 (London: Edward Elgar Publishing, 2017).

Prodjodikoro, Wirjono, Hukum Antar-Golongan di Indonesia (Bandung: Sumur, 1962).

Purwosutjipto, H. M. N., Pengertian Hukum Dagang Indonesia 2: Bentuk-bentuk Perusahaan (Jakarta: Djambatan, 1995).

Rechtshoogeschool, Jaarboekje der Rechtshoogeschool te Batavia 1927 (Batavia: G. Kolff \& Co., 1927).

Rosidi, Ajip, Undang-Undang Hak Cipta 1982: Pandangan Seorang Awam. Jakarta: Djambatan, 1984).

Simorangkir, J. C. T. Pembinaan Hukum bagi Masyarakat Indonesia (Jakarta: Badan Pembinaan Hukum Nasional, 1980).

Slametmuljana, Perundang-undangan Madjapahit (Jakarta: Bhratara, 1967).

Steenhoff, G. J. W., "Roeland Duco Kollewjin (18921972)", dalam Gerard J. Tanja (ed.), The Moulding of International Law: Ten Dutch Proponents (The Hague: T. M. C. Asser Institute, 1995).

Stroomberg, J., Hindia Belanda 1930, diterjemahkan oleh Heri Apriyono (Yogyakarta: IRCiSoD, 2018).

Sumantoro, Problems of Investment in Equities and in Securities (Jakarta: Binacipta, 1984).

Supomo, Sistem Hukum di Indonesia Sebelum Perang Dunia II (Jakarta: Prandya Paramita, 1981).

Subekti, Bunga Rampai Ilmu Hukum (Bandung: Alumni, 1983).

Tjitrowinoto, Soebijono, Ichtisar tentang Hukum di Indonesia (Malang: Rahma Kongsi, 1953).

Utrecht, E., Pengantar dalam Hukum Indonesia (Jakarta: Penerbitan dan Balai Buku Indonesia, 1961).

Wahyono, Padmo, Pendidikan Tinggi Hukum di Indonesia (Jakarta: Firma Widjaya dan Yayasan Tritura '66, 1990).

Wignjosoebroto, Soetandyo, Dari Hukum Kolonial ke Hukum Nasional: Suatu Kajian tentang Dinamika Sosial-politik dalam Perkembangan Hukum Selama Satu Setengah Abad di Indonesia, 18401990 (Jakarta: RajaGrafindo, 1994). 


\section{Makalah/Artikel/Prosiding/Hasil Penelitian}

Badan Pembinaan Hukum Nasional, Lokakarya Hukum Perdata Internasional (Jakarta: Badan Pembinaan Hukum Nasional, 1984).

Makarim, Nono Anwar, Mengada-ada Perseroan Terbatas (Jakarta: Pusat Studi Hukum dan Ekonomi, Fakultas Hukum Universitas Indonesia, 1977).

Gouw Giok Siong, Hukum Antargolongan Hukum yang Hidup! Pidato pengukuhan guru besar luar biasa dalam ilmu hukum perselisihan, (Jakarta: Fakultas Hukum dan Pengetahuan Masyarakat Universitas Indonesia, 1958).

Gautama, Sudargo, "Indonesia dan Konvensikonvensi tentang Hak Cipta," Majalah Fakultas Hukum Universitas Indonesia, 3 (1975).

Gouw Giok Siong, "Tinjauan Buku: Prof. Mr. R. D. Kollewijn, Intergentiel Recht Verzamelde opstellen over intergentiel privaatrecht," Majalah Hukum dan Masjarakat, 4 (1956).

Hatta, Mohammad, Lampau dan Datang, pidato penerimaan doctor honoris causa dari Universitas Gajah Mada (Yogyakarta: Universitas Gajah Mada, 1956).

Koesnoe, Moh., "Arti, Tempat, dan Sifat Hukum Intergentil," Majalah Hukum dan Masyarakat, 2 (1957).

Kollewijn, R. D., "Intergentiel Privaatrecht," Indisch Tijdschrift van het Recht 131 (1930).

Kollewijn, R. D., "Conflicts of Western and NonWestern Law," The International Law Quarterly, 4 (1951).

Oey Pek Hong, Peranan Kodifikasi, Jurisprudensi dan IImu Pengetahuan dalam Perkembangan Hukum Perdata, pidato pengukuhan guru besar (Surabaya: Fakultas Hukum Universitas Airlangga, 1959).

Oppusunggu, Yu Un, "In Memoriam Prof. Mr. Dr. Sudargo Gautama," Jurnal Hukum dan Pembangunan, 38 (2008).

Oppusunggu, Yu Un, "Mandatory Corporate Social and Environment Responsibility in the New Indonesian Limited Liability Law," Indonesian Law Review, I (2011).

Oppusunggu, Yu Un, Naskah Akademik Rancangan Undang-Undang tentang Perseroan Terbatas (Jakarta: Badan Pembinaan Hukum Nasional, 2016).

Oppusunggu, Yu Un, Sudargo Gautama and the Development of Indonesian Public Order: A Study on the Application of Public Order Doctrine in a Pluralistic Legal System, disertasi (Seattle: University of Washington, 2015).

Pompe, S. dan C. de Waaij-Vosters, "The End of Hukum Antargolongan," Bijdragen tot de Taal-, Lad-en Volkenkunde, 145 (1989).

Soekanto, Soerjono, "Pokok-pokok Penyusunan Silabus Kurikulum Fakultas Hukum," Hukum dan Pembangunan 5 (1986).

Supomo, "Hukum Adat di Kemudian Hari Berhubung dengan Pembinaan Negara Indonesia," Hukum Madjallah Perhimpunan Ahli-Hukum Indonesia, 4-5 (1952).

Supomo, Kedudukan Hukum Adat di Kemudian Hari. Orasi ilmiah pada dies natalies Universitas Gajah Mada, 17 Maret 1947 (Yogyakarta: Universitas Gajah Mada, 1947).

Syah, St. Malikul, “Mr. R. D. Kollewijn: Intergentiel recht Verzamelde opstellen over intergentiel privaatrecht," Hukum, 3-4 (1956).

Thung Tiang Piet, "Cita-cita Kodifikasi dan Unifikasi di Indonesia dan Perbandingan Hukum," Majalah Hukum dan Masyarakat 3 (1958).

Sullivan, John H., The United States and the 'New Order' in Indonesia, disertasi (Washington D. C.: American University, 1969).

Supancana, I. B. R., et al., Naskah Akademik Rancangan Undang-Undang Hukum Perdata Internasional (Jakarta: Badan Pembinaan Hukum Nasional, 2015).

\section{Peraturan Hindia Belanda}

Wetboek van Koophandel [Kitab Undang-Undang Hukum Dagang], S. 1847-23.

Reglement op de Rechterlijke Organisatie en het Beleid der Justitie in Indonesië [Peraturan tentang Susunan Kehakiman dan Kebijaksanaan Mengadili di Indonesia], S. 1847-23 jo. 1848-57.

Reglement op het beleide der Regering van Nederlandsch-Indië [Peraturan tentang Pemerintahan Hindia Belanda], S. 1855-2.

Bepalingen, houdende toepasselijk verklaring van de Europesche Wetgeving op de met de Inlandsche Gelijkgestelde Bevolking [Penetapan, Memuat Pernyataan Keberlakuan Peraturan Eropa terhadap Golongan Rakyat Indonesia], S. 185579-129

Toepasselijk-verklaring op de Inlandsche en met deze Gelijkgestelde Bevolking van de Artikelen 1601, 1602 en 1603 van het Burgerlijk Wetboek [Pernyataan Keberlakuan Pasal-pasal 1601, 1602 dan 1603 dari Kitab Undang-Undang Hukum 
Perdata terhadap Golongan Rakyat Indonesia dan Yang Dipersamakan], S. 1879-256.

Reglement voor de Opleidingsschool voor Inlandsche rechtskundingen [Peraturan untuk Sekolah Pendidikan untuk Ahli Hukum Pribumi], S. 190993.

Auteurswet [Undang-Undang Pencipta], S. 1912600.

Bepalingen voor geheel Indonesië betreffende het burgerlijk en handelsrecht van de Chineezen [Penetapan untuk seluruh Indonesia tentang hukum perdata dan hukum dagang untuk Tionghoa], S. 1917-129

Hooger Onderwijs-ordonnatie [Ordonansi Pendidikan Tinggi], S. 1924-456.

Bepalingen voor geheel Indonesië betreffende het het burgerlijk en handelsrecht der Vreemde Ooosterlingen Andere dan Chineezen [Penetapan untuk seluruh Indonesia tentang hukum perdata dan hukum dagang untuk Timur Asing Selain Tionghoa], S. 1924-556.

Wet op de Staatsinrichting van Nederlandsch-Indie [Undang-Undang tentang Ketatanegaraan Hindia Belanda], S. 1925-447.

Bepaling dat de in 1928 te Rome gesloten Herziene Berner Conventie ter bescherming van letterkundige- en kunstwerken op 1 Augustus 1931 voor Nederlandsch-Indië van kracht wordt [Penetapan tentang Konvensi Berne untuk Perlindungan Karya Sastra dan Senin, yang dibuat di Roma pada 1928, akan berlaku pada 1 Agustus 1931 untuk Hindia Belanda], S. 1931325.

Ordonnantie op de Inlandsche Maatschappijen op Aandeelen [Peraturan tentang Maskapai Andil Indonesia], S. 1939-569.

\section{Peraturan Indonesia}

Undang-Undang Dasar 1945 (Naskah Asli).

Undang-Undang Dasar Negara Republik Indonesia Tahun 1945.

Undang-Undang Dasar Sementara Republik Indonesia.

Undang-Undang No. 3 Tahun 1946 tentang Warga Negara dan Penduduk Negara.

Undang-Undang No. 5 Tahun 1960 tentang Peraturan Dasar Pokok-pokok Agraria, LNRI 1960-104.

Undang-Undang No. 1 Tahun 1967 tentang Penanaman Modal Asing, LNRI 1967-1, TLNRI 2818.
Undang-Undang No. 5 Tahun 1968 tentang Persetujuan atas Konvensi tentang Penyelesaian Perselisihan antara Negara dan Warga Negara Asing mengenai Penanaman Modal, LNRI 196832, TLNRI 2852.

Undang-Undang No. 4 Tahun 1971 tentang Perubahan dan Penambahan atas Ketentuan Pasal 54 Kitab Undang-Undang Hukum Dagang (S. 1847-23), LNRI 1971-20.

Undang-Undang No. 1 Tahun 1974 tentang Perkawinan, LNRI 1974-1, TLNRI 3019.

Undang-Undang No. 6 Tahun 1982 tentang Hak Cipta, LNRI 1982-15, TLNRI 3217.

Undang-Undang No. 7 Tahun 1987 tentang Perubahan atas Undang-Undang No. 6 Tahun 1982 tentang Hak Cipta, LNRI 1987-42, TLNRI 3362.

Undang-Undang No. 7 Tahun 1994 tentang Pengesahan Agreement Establishing the World Trade Organization, LNRI 1994-57, TLNRI 57.

Undang-Undang No. 1 Tahun 1995 tentang Perseroan Terbatas, LNRI 1995-13, TLNRI 3587.

Undang-Undang No. 12 Tahun 1997 tentang Perubahan atas Undang-Undang No. 6 Tahun 1982 tentang Hak Cipta Sebagaimana Telah Diubah dengan Undang-Undang No. 7 Tahun 1987, LNRI 1997-29, TLNRI 2679.

Undang-Undang No. 30 Tahun 1999 tentang Arbitrase dan Penyelesaian Sengketa, LNRI 1999-138, TLNRI 3872.

Undang-Undang No. 21 Tahun 2001 tentang Otonomi Khusus bagi Provinsi Papua, LNRI 2001-135, TLNRI 4151 sebagaimana diubah oleh Undang-Undang No. 35 Tahun 2008 tentang Penetapan Peraturan Pemerintah Pengganti Undang-Undang No. 1 Tahun 2008 tentang Perubahan Undang-Undang No. 21 Tahun 2001 tentang Otonomi Khusus bagi Provinsi Papua Menjadi Undang-Undang, LNRI 2008-112, TLNRI 4884.

Undang-Undang No. 19 Tahun 2002 tentang Hak Cipta, LNRI 2002-85, TLNRI 4220.

Undang-Undang No. 11 Tahun 2006 tentang Pemerintahan Aceh, LNRI 2006-62, TLNRI 4633.

Undang-Undang No. 28 Tahun 2014 tentang Hak Cipta, LNRI 2014-266, TLNRI 5599.

Keputusan Presiden Republik Indonesia Serikat No. 33 Tahun 1950 tentang Pengumuman Dokumendokumen Konferensi Meja Bundar, LNRIS 19502.

Keputusan Presiden No. 34 Tahun 1981, tentang Pengesahan Convention on the Recognition and 
Enforcement of Foreign Arbitral Awrds, LNRI 1981-40.

Keputusan Presiden No. 31 Tahun 1986 tentang Pengesahan Convention Establishing the Multilateral Investment Guarantee Agency, LNRI 1986-45.

Keputusan Presiden No. 18 Tahun 1997 tentang Pengesahan Berne Convention for the Protection of Literary and Artistic Works, LNRI 1997-35.

Instruksi Presidium Kabinet No. 31/U/IN/12/1966.

Peraturan Mahkamah Agung No. 1 Tahun 1990 tentang Tata Cara Pelaksanaan Putusan Arbitrase Asing

\section{Perjanjian Internasional}

Agreement Establishing the World Trade Organization [Persetujuan Pembentukan Organisasi Perdagangan Dunia].

\section{Rancangan Undang-Undang}

Departemen Kehakiman Republik Indonesia. Rancangan Undang-Undang Hukum Perdata Internasional, 1997/1998.

\section{Putusan Pengadilan}

Ldr. Malang, 16 Februari 1938, T. 148 (1939): 764 sebagaimana terdapat dalam Gouw Giok Siong. Himpunan Keputusan-keputusan Hukum Antargolongan (Jakarta: Penerbitan Universitas, 1959).

Lie Kwie Hien v. Tjin Tjheuw Jie, 5 Desember 1953, Putusan Pengadilan Negeri Jakarta, No. 373/1952 G, sebagaimana terdapat dalam Sudargo Gautama, Landmark Decisions, Jilid 1 (Bandung: Alumni, 1992).

Navigation Maritime Bulgare (Bulgaria) v. PT Nizwar, Putusan Mahkamah Agung Republik Indonesia No. 2944 K/Pdt/1983, sebagaimana termuat dalam Varia Peradilan 18 (1987).

E. D. \& F. MAN (Sugar) v. Yani Haryanto, Putusan Mahkamah Agung No. 12 K/Pdt/1990, sebagaimana terdapat dalam Sudargo Gautama, Landmark Decisions, Jilid 3 (Bandung: Alumni, 1993). 